\title{
Social Capital in Dealing with Neo-Patrimonial Governance of Street Vendors
}

\author{
Sudarmo \\ The Study Program of Public Administration \\ Faculty of Social and Political Science, Universitas Sebelas Maret \\ J1. Ir. Sutami No. 36A Surakarta, Jawa Tengah, 57126, INDONESIA \\ sudarmo63@yahoo.com
}

\begin{abstract}
This paper is intended to examine networks made by street vendors in dealing with local government actions affecting their livelihood. The study shows that the local governments dominate the process of decision-making, and governance of street vendors still continues through a top-down approach. The tradition of a centralistic approach compounded by the neo-patrimonial governance in public decision making is not entirely removed yet. The study concludes that creating social capital is essential for survival as a street trader in the urban areas. The more links street vendors have the more likely they are to be able to survive; those who have the least networks with other stakeholders are the most vulnerable.
\end{abstract}

Keywords: street vendors; social capital; neo-patrimonial governance; local government; decision making

\section{INTRODUCTION}

The number of street vendors in urban areas has grown significantly in the post Suharto reforms period. Some of the factors behind the rise of the number of street traders included rural-urban migration of lowskilled workers into cities, redundancies caused by the worsening economic crisis and lack of employment opportunities in the formal sectors [1]. Street vending growing in urban areas is not only a source of selfemployment to the poor in the cities and towns but also a means to deliver inexpensive as well as practical services to majority of the urban population $[2,3,4,5,6]$. Street vending varies in terms of scale, timing, location, remuneration, workforce and types of goods sold and services provided [7]. Street vendors may help many small-scale industries to succeed by selling the products that they produce $[8,9]$.

Although it is very difficult to provide an accurate estimation of the number of street vendors, it had been growing in the urban areas of Wonogiri District and Semarang Municipality in Central Java Province, before the post-1998 era of reform, and it has significantly increased since the economic crisis in 1997. This however was not unique to the urban areas as the number of street traders had been increasing worldwide [8].
The number of street vendors in Semarang Municipality was just below 2,000 in 2000, however Market Office statistics shows that it increased dramatically to almost 11.500 in 2009 , and to about 12.000 in 2012. Out of which around 200 occupied the Kartini Street, a location nearby the traditional market of Karimata where authorized traders sold similar goods to those offered by the street vendors. Similarly, the number of street vendors in the urban areas of Wonogiri district increased gradually. It was below a hundred in the early 2000s, yet over a decade it increased to about 750 in early 2010, when Begug Purnomosidi's administration ended. Three years later, it increased to 2000, out of which 650 were in the urban areas of Wonogiri, and 200 out of 650 were in the center city of Wonogiri.

The local government tends to see street vendors negatively, namely as being part of an increasing urban slum, rather than in a positive way as providers of a certain economic benefit. Consequently, their existence was controlled by application of the local laws. The current policy paradigm and legislative regime are indeed unsympathetic towards the street vendors.

This paper is intended to examine networks made by bird street vendors of the P3BS group in countering conflict with the formal bird traders of Karimata Market at Kartini Street and in dealing with the Semarang Municipal policy. This paper also discusses links formed by culinary street vendors groups at urban center of Wonogiri District in responding local government actions affecting their livelihood. It discusses evidence of governing the street vendors during the Mayor Sumarmo Hadi Saputro (2010-2012) and Mayor Hendrar Prihadi (2013-15) in Semarang Municipality and Regent Begug Purnomosidi (2000-2005 and 2005-2010) and Danar Rahmanto (2010-2015) in Wonogiri District. Since 2005 all regents and Mayors in Indonesia had been elected democratically by his or her constituents. This paper argues that although there was a transition towards democratic elections for mayors and regents throughout Indonesia, in the post-Suharto reforms period, Semarang Municipality and Wonogiri District still represent the traditional polities. These polities have patrimonial features that meet the definition of personal rule system; the one in which local rule on street vendors was 
inconsistently implemented; different officials had different discretion in dealing with street vendors; one official may spoil street vendors but another may control them strictly. This paper argues that creating networks through social capital is very important for survival as a street trader in Wonogiri and Semarang; the more links a street vendor has, the more likely he/she is going to be able to survive; street vendors who are excluded and those who have the least networks in Wonogiri and Semarang are the most vulnerable.

\section{THEORETICAL REVIEW}

Street vending as an occupation has existed for hundreds of years [7], and has become an integral component of most urban economies [1]. Street vending is one of the key manifestations of urban poverty, especially in developing countries [10]. It is an entry level profession due to ease of entry and exits, low initial and working capital requirement, and flexible work hours [11]. In almost all Asian countries, including Indonesia, street vendors have no legal status to conduct their business, and they are continuously harassed by the authorities [12]. Although street vending is a thriving and growing phenomenon [13, 14], it experiences various problems of removal that undermines their livelihood and survival.

A street vendor can be defined as 'a person who offers goods or services for sale to the public without having a permanent built-up structure but with a temporary static structure or mobile stall' [15]. They may become stationary by occupying some space on the pavements or other public areas. Most street vendors are identified as self-employed workers in the informal sector who offer their labor to sell goods and services on the street, without having any permanent built-up structure [16], although some do have virtually-permanent built-up structure.

In most countries including Indonesia, where the number of street vendors was large, the ruling parties used the vendors for their political gains. Nonetheless the street traders themselves did not always get any tangible benefits from the alliance [12]. Some large retail stores, authorized traders that run traditional market fearing competition with informal traders, as well as those who have personal or political links with the local governments, may frequently lobby local governments for the street vendors' suppression. In addition, some governments co-opted the leaders of street vendors in order to support their policy which may undermine the rest of the members of the street vendors' community. All these unspoken conventions may be seen as some of the characteristics of patrimonial governance of street vendors.

Patrimonialism is a power regime based on the personal power of the patron, and his/her discretionary ability to dispense favor and resources to clients, who in turn rule as sub-patrons within their own domains [17]. This personalist power represents a negative rule, leading to dysfunctional democracies and causing various electorate activisms [18]. While patrimonialism refers to a power regime based on personal power, patrimonial governance refers to a process or the way the patrimonial regime govern; it is a process and situation where administrative positions and structures are set up by patrons who then assign authority to deputies over certain parts of the overall patronage domain $[19,17]$. In the patrimonial governance, the distinction between private and official, personal and public, is made formally, political action is normatively discussed in terms of legal accountability, legitimating for such action is sought in terms of public norms and universal ideologies, and modern bureaucratic institutions and formal-legal rules do exist [20, 21]. In practice, however, these norms and rules make place for obviously personalized politics, a 'shadow state' [22], which 'leaves the formal institutions of government little more than an empty shell' [23]. Such a dual political system of governance, in which patrimonial politics exist next to, and feed off, modern bureaucracies, has been described as neopatrimonialism [24].

Neo-patrimonial governance can manifest itself in different forms. Neo-patrimonialism may represent patron-client relationships that remain common in Southeast Asia, South America and other less-developed countries [25]. It represents ties involving a largely instrumental friendship in which an individual of higher social-economic status (the patron) uses his influence and resources to provide protection or benefits, or both, for a person of lower status (the client). The client, for his part, reciprocates by offering general support and assistance, including personal services to the patron [25]. Neopatrimonialism may also represent political clientelism, since it is 'the distribution of resources (or promise of) by political officeholders or political candidates in exchange for political support, primarily though not exclusively in the form of the vote' $[26,27]$.

It was argued that neo-patrimonial governance seems to be the best suited to the least developed countries, where relatively simple economic structures are more responsive to relationship-based governance, and looks the most viable route to pro-poor growth [28]. However, I argue that this is not entirely suitable in the context of the street vendors governance in Indonesia, particularly in urban areas of Wonogiri and Semarang, for the reason that most street vendors demand for democratic valuesbased policy decision making; the one that involves street vendors' participation. The discussion above implies that neopatrimonialism governance of street vendors may represent a situation where government apparatuses' actions are arbitrary (based on subjective reasoning, following ad hoc procedures), rules are applied only partially, and some citizens get preferential treatment. Inconsistence of the policy implementation and rule, excessive discretion to those who have personal or political links, all at the expense of powerless street vendors, may undermine democratic values. Thus this situation may be responded by formation of networks of opposed street vendors through social capital used to defend themselves from government or elites' actions that may challenge their survival, despite the fact that their attempts are not always successful [29].

Pellini and Ayress [30] underline the importance of social capital in governance; they argue that "in order to build a local governance and local development model that is culturally appropriate and therefore legitimate, the model should support existing social capital, strengthening relationship between group and association at the community level, and between these groups and the commune. However, in patrimonial rule, the group leaders could be co-opted and misused by the 
government to influence their followers or members to support the government's policy, again at the expense of the powerless street vendors [31].

Social capital can be seen as 'an approach characterizing the trust of people with one-another, the trend to be united with them in groups and social networks and the development by means of cooperation of the reciprocity value norms to achieve expected results or outcomes' [32]. It is also 'an all-encompassing term for the norms and the social networks that facilitate cooperation among individual and between groups of individual' [33] and 'the norms and networks that enable people to act collectively' [34]. In this paper, the term social capital is defined as the norms and networks that enable members of a group of street vendors cooperate and act collectively to each other, enable them as a group cooperating with other non-governmental groups, as well as government through lobbies, personal or political links (although it may be at the expense of other powerless street vendors).

Social capital can be divided into three types: a) bonding social capital, b) bridging social capital, and c) and linking social capital [33, 35, 36, 37, 34, 38, 39]. Bonding social capital involves linkages or strong ties within groups of like-minded individuals that often correspond to denser and more localized networks [34]. In this kind of social capital, behavior, rules and expectations are known and met by people who shares values, ideas and relationship. Since this kind of social capital can exist in social groups such as aristocratic families, street vendors' associations, formal business groups, and informal security or thugs (that operate in the trading areas of street vendors), the results can be elitist, negative and destructive, providing that the rules and networks are used to exclude others, namely those who do not conform. Therefore, the social capital can represent a form of resistance to change, an attitude of preserving the status quo, but it may also have positive effects for the members belonging to a closed social group or network. Strong ties are particularly useful in the context of informal trade for the reason that they are associated with the trust and cooperation which - in turn - can encourage an individual street trader to examine trading rules and sustainable trading practices for his or her survival, and consequently build sense of solidarity in order to protect his or her friends.

Bridging Social capital, on the other hand, is concerned with linkages across similar, but different, groups or social networks [34]. Although these bonds of connectivity 'are often much weaker between heterogeneous groups than within a relatively homogenous group they can be very important as they provide a critical mechanism for the diffusion of knowledge and innovation' [34]. In governance of street vendors, bridging social capital may also play a crucial role in strengthening and improving cooperation among location-based groups, city wide associations and between location-based groups and city wide associations of street vendors. In addition, it can contribute to conflict resolution across competing informal trading mechanism and interests.

Finally, a linking social capital refers not only to 'relationships between individuals and groups in different social strata in hierarchy where power, social status and wealth are accessed by different groups' [40], but also has 'the capacity to leverage resources, ideas and information from formal institution beyond the community' [41]. For example, links between street vendors and other institutions such as formal business groups, leading aristocratic families, city governments, local NGOs, local residents, and other grassroots of social groups. Linking social capital may include 'involvement and inclusion, and work towards institutional change to empower members of community (through decision making, representation and participation, education and training, mentoring and support networks)'. Such links are "required" if the governance of street vendors is "to be effectively shared" [34]. These links can also "create the condition and spaces that facilitate collective action" of street vendors and other institutions of different social strata [42, 43, 44, 45]. However, as street vendors may have been living in exclusion from public decision making (in which powerful groups may use their decision to regulate or control them and thus affect their source of revenue), developing and strengthening linking by individual (or groups of) street vendors across different groups and networks, at different hierarchies, this might be rather useful for their survival in order to support them.

The above discussions suggest that creating networks through social capital is essential for survival as a street trader in Wonogiri and Semarang. The more links street vendors have the more likely they are able to survive. Street vendors who are excluded and those who have the least networks in Wonogiri and Semarang are the most vulnerable.

\section{METHODS}

This research used an ethnographic method, involving several periods of fieldwork using participant observation, spending much time watching people, talking with them about what they were doing, thinking and saying. The study focuses in particular street vendors, their views, their motivations, their attitudes, and their interaction with other stakeholders. The study is also an examination of the dynamics, powers and local government actions and policies regarding the street vendors in the urban areas of Wonogiri and Semarang. The fieldwork was carried out in the periods of June 2014 to July 2015 in the areas of Wonogiri; additionally between January to November 2012 and March to December 2014 in Semarang.

The study uses mixed method research [46] where the qualitative approach predominates over the quantitative one. The population of the study covers all the street vendors and their associations in the urban areas of Semarang Municipality and Wonogiri District. Ten groups of street vendors were selected as samples: a) six location-based groups in Semarang including a bird street vendor group called the P3BS in Kartini Street, four groups of culinary street vendors in Simpang Lima area and KB Park, and a formal business group of Karimata Traditional Market, b) four location-based groups in Wonogiri including Dwi Margo Mulyo, district- wide association of street vendors called Persatuan Pedagang Kaki Lima Wonogiri (PPKLW), Gudang Seng group, and street vendor group around traditional markets of Wonogiri. The data collection techniques include in-depth interviews, focusedgroups, participant observations and document reviews. Short questionnaires with the majority of open-ended questions were 
distributed to 80 street vendors. The street vendors were divided into subpopulations according to the location of vending sites. The questionnaires were distributed to 80 culinary street vendors consisting of 40 in Simpang Lima Parks, 40 in Taman $\mathrm{KB}, 50$ authorized bird traders in Karimata Market and 40 bird street traders in Kartini Street in Semarang; and 40 culinary street vendors and 15 authorized culinary traders in Wonogiri; The rationale was that street traders as well as other traders are not a homogenous group in terms of age, income, gender, time spent on the street, and the experience of having conflict and interaction with the local government. Short questionnaires with the majority of open-ended questions were also distributed to 30 local inhabitants of the non-street vendors, 40 road users who were driving their cars or motorcycles in Semarang and Wonogiri. Hence a more representative sample could be obtained through the stratified sampling technique. Stratified sampling is also allowed for intentional oversampling which permits greater statistical precision [47]. In order to deepen the study, a number of in-depth interviews were held with: (a) all of the group leaders of culinary as well as bird street vendors, (b) two officials from each of the local governments, (c) group leaders of authorized bird traders of Karimata Market, (d) ten local inhabitants living around the locations where street vendors run their informal shops. The validity of this study was maintained by using multiple data sources (triangulation of data sources) or multiple information sources by using various informants and various documentary data and methods of data collection.

\section{RESULTS AND DISCUSSION}

Evidence from Wonogiri shows certain patrimonial features in the governance of street vendors. During the era of Regent Begug Purnomisidi (elected for two periods 2000-2005 and 2005-2010), the local government of Wonogiri provided facilities for street vendors. The regent issued Regent Decree 2/2007 on the guideline of the implementation of Local law 7/2006 on Regulation and Control for street vendors. This Regent Decree represented a law with excessive discretion for street vendors for the reason that it allowed the street vendors to run their business in some restricted locations of public spaces in the urban areas that are forbidden according to the Local Law 7/2006. The Decree was intended to provide law protection to street vendors especially those who have links to Regent. The local government in cooperation with Mandiri Bank in 2007 provided soft loan amounting between four and five million rupiahs for one hundred street vendors. The local government also invited the Coca-Cola Company to provide a quasipermanent stall for food-selling street vendors in the center of the town as to be used as a pilot project of local culinary tourism; and definitely to meet the Regent's interests. However, not all officials of Wonogiri District took the side with street vendors; some of the Administrative Enforcement Police officials who normally enforced the local law did not agree to spoil street vendors with many facilities because they worried that street vendors would grow up and create disturbances to urban lives. Despite their disagreement, they could not reject the regent's policy that permitted street vendors to develop and enjoy the regent's discretion for achieving his political gain. The Regent of Wonogiri District also held traditional celebration in the form of annual parade in coincidence with National days, such as the Independence Day of the Republic of
Indonesia. In this event, the local government encouraged street vendors to display their potential businesses to local tourists.

However, although the local government's policy provides many opportunities to street vendors based on personal ties representing, excessive discretion was not always at the expense of other stakeholders: none of 15 $(0 \%)$ respondents of formal culinary traders of traditional market of Wonogiri reported that they suffered from income decline because of both formal and informal traders operating in different times although their commodities were similar and they have different segments of customers; only 5 out of $30(16,67 \%)$ local inhabitants of Wonogiri were dissatisfied by Begug's policy despite his taking the side with street vendors because most street vendors could maintain the city cleanliness; only 8 out of $40(20 \%)$ road users who were driving their cars or motorcycles were complaining about traffic jam and problems of safety but most of them do not mind with the street vendors because most of them run their business during the night time where the situation of the city was not crowded. The statistic shows $15.29 \%$ of 85 respondents consisting of combined culinary formal traders, local inhabitants living around the area of market and locations of street vendors, and road users recognized that local government's policy under Begug Purnomosidi on street vendors does not affect them significantly despite his taking the side with the street vendors and because the ruling parties as well as the Regent used the vendors for their political gains. After his power ended in 2010, Begug nominated himself as Vice Regent candidate for the period 2010-2015 but he failed to be re-elected due to his incapability to provide satisfying public service to all stakeholders when he held the power.

Unfortunately, since the ruling period of Begug Purnomisidi ended, and then replaced by Mayor Danar Rahmanto, the situation of street vendors changed entirely. All social and economic supports of the local government to street vendors also ceased. The current Regent acted strictly; he was quite repressive towards the street vendors and did not facilitate them to participate in public decision-making processes. The local government tried to remove street vendors coercively from the center of Wonogiri city by reducing the width of pavement from two meters or more as was built under Begug's administration to only one meter so that the street vendors could not use it easily to run their informal business. As the substitute of the pavement, the Local Government promised to provide satisfying and strategic area located at the southern traditional market of Wonogiri City and would relocate them into the market in the mid of May 2012 but until the mid of July 2015 the local government was still not willing to relocate them to the promised areas because the area where many new kiosks had been constructed were provided only for large traders who are more capable of paying higher rent. At the same time, the local government tried to remove street vendors by reducing the two meter-wide pavement they used so far to one meter so that it affected their customers' comfort and it was potential to make their customers leave them and could threaten street vendors' future livelihood. Despite this coercive policy and their being powerless, street vendor groups running businesses 
at the northern area of traditional market of the city tried to defend themselves from the removal attempts.

The local government, in alliance with local police office, also implemented the Friday Clean Program (Program Jum'at Bersih) intended to remove street vendors from their site of operation since the mid-2013. At the beginning street vendors perceived this program as a part of the local government's concern to help them maintain the cleanliness of their business location environment, and it engaged leaders of street vendor groups to join this program and asked them to coordinate their member groups to work together with local government apparatuses as well as police every Friday morning. However, this program is secretly intended to remove street vendors entirely from their locations. During the program implementation, any street vendor who was found to be absent from running their informal business on that day, his or her shelter would be confiscated and his or her goods was removed from their locations. Street vendors' request to get involved in public-decision making that affected their lives was not accommodated, and the local government maintained top-down approach in any public decision making which did not accommodate street vendors' interest. This situation directly affected the street vendors' livelihood; their future was threatened and undermined. This situation encouraged street vendor to attempt to build links to the local government officers, mainly to officers of the Administrative Enforcement Police Office, but it failed because the officers perceived that the street vendors had broken the local law. The street vendors themselves did not have personal links to the current Regent who was basically a rich and large businessman and he did not have personal ties with any street vendor leader in Wonogiri. Street vendors also recognized that they were not the constituent of the current regent. The strict policy issued by the current regent was intended to show his responsibility to his constituents who were mostly non street vendors, and thus, the ruling parties as well as the current regent used the eviction program of street vendors for their political gains.

Finally, due to the intensive government pressure while street vendors did not have personal links to the current regent, they strengthened their cohesiveness between members of the group in creating bonding social capital and they built networks between location-based groups in Wonogiri District by forming a district-wide street vendors association, the PPKLW, on $5^{\text {th }}$ June 2013 as a part of their attempts to create bridging social capital. In order to strengthen their position, this district-wide group also built networks with other local communities including the Farmer Group of Gajah Mungkur as well as Big Motor Group of Wonogiri. The PPKLW also built personal links with Bondan Sejiwan Boma Aji, a young entrepreneur, who is also a member of the local legislature and a candidate of the next Wonogiri regent. $\mathrm{He}$ is famous for taking the side with the marginalized communities, such as street vendors. Recently, the street vendors of Wonogiri have prepared to support him as a candidate of the next Wonogiri Regent, for the period of 2016 to 2021 . In addition to personal links or networks to the non-government stakeholders, street vendors who are now under pressured, used confrontation or conflict approach to any government's policy that affect their lives. All of these efforts, to some extent, had strengthened street vendors political bargain in dealing with the current regent's undermining policy although they were not able to force the local government to allow street vendors participating in public decision making forum that affected their lives.

Similar evidence has been extracted from the case of Semarang. There, bird street vendors on Kartini Street had grown gradually since early 2000. Between 2000 and 2005 the number reached hundreds but they were unorganized so that they were fragile; they experienced several removals by local government apparatuses, and due to the government's actions most of their income lost up to $80 \%$ on average and many others went bankrupt and disappeared. Some who were able to keep their survival joined with the new street bird traders, and due to past experience of having removals, they formed a group of Semarang bird street vendors (P3BS) in 2006. The location where they run their business is about 25 meters away from that of Karimata Market where 200 authorized bird traders offered similar goods. The street vendors were perceived as doing unfair competition to the authorized bird traders of the Karimata traditional market. However, the street vendors had personal and political links with the former Mayor Soemarmo who got his power in 2010 , but ended his mayoral authority in 2012, due to graft allegations. During his political campaign for mayoral elections affiliated to PDIP (Indonesian Democratic Party Struggle), Soemarmo obtained full support from the P3BS group. As a reward of their support, they were allowed to run their business on the restricted areas at the expense of authorized traders of Karimata, who sell similar goods nearby the location of the P3BS. The authorized traders of Karimata in numerous occasions sent letters to the mayor objecting the P3BS's existence there and perceived as having unfair competition. However, the Mayor did not give satisfying responses. The Karimata traders also (more than once) visited the Mayoral office and asked Mayor Soemarmo for a more fair treatment, but again he did not provide any expected solution. Therefore, expectations for a more fair solution set by the authorized Karimata street vendors could not be realized due to the poor links with the Mayor.

Furthermore, there are other evidence showing a strong personal and political links between the Mayor and the P3BS. When Semarang Court decided to fight against Soemarmo in 2012, his supporters including street vendors conducted protests to the court. The P3BS was also successful in making a bridging social capital with the other community groups. These groups provided protection to the groups from the non-government intimidation, as well as their competitors. However, since Mayor Soemarmo had been sent to prison, mayoral power was officially held by his vice, Hendrar Prihadi. He was not a PDIP candidate and he got into power as a Mayor of Semarang Municipality since 2013. Mayor Hendrar Prihadi who got many complaints from authorized Karimata traders had tried to be responsive to the demand. He had instructed his subordinate to remove the street vendors from Kartini Street based on the repressive Local Law 11/2000 which is basically a revision of the old Local Law 3/1998. Nevertheless, the P3BS was able to survive on the street, for the reason that this group has had the capability to lobby the local government, and built networks with other community 
groups, including the local NGO's and local residents who supported them. In addition, the P3BS made personal links to Lurah, the village head, intended to gain his protection from eviction. Although the P3BS nowadays is gravely controlled by the Office of Market, the Office of Satuan Polisi Pamong Praja (Administrative Enforcement Police) the Road Transportation Traffic Office (and the local government had given an ultimatum for removal at the end of 2013) this group still survived on the street, at least until the end of September 2014 mainly due to their capability to lobby and built networks with other non-government powerful groups, in order to obtain their support and protection.

Despite authorized Karimata traders' objection where 50 out of 50 respondents $(100 \%)$ reject the presence of bird street vendors on Kartini Street because they affect their income loss up to $85 \%$ of total income; only 6 out of $30(20 \%)$ local inhabitants are dissatisfied by the Soemarmo as well as Hendrar Prihadi's Policy on street vendors and $80 \%$ could accept street vendors because they perceived that street vendors work as such for their survival, and in addition they did not mind although the street vendors' activities would finish at 5 pm every day because they were totally responsible for the location to be cleaned. Similarly, most road users also did not mind; only 4 out of $40(10 \%)$ road users who were driving their cars or motorcycles were complaining, not because of the street vendors but because of the parking attendants who were not able to arrange the parking vehicles and because there were many pedicabs parked nearby the location.

Basically both Mayor Soemarmo and Hendrar Prihadi had different political party's affiliation and treatment on the bird street vendor group of the P3B as well as the Formal bird trader group of Karimata Traditional Market, but they both spoiled culinary street vendors and have similar treatment on them mainly to those who were around Simpang Lima area and the KB Park because they both used the vendors for their personal political gains as it did also happen in Wonogiri. They planned these areas to be a center of local culinary tourism of Semarang City. During the two Mayor's administration periods, the municipal government spent billions rupiahs to provide many facilities such as permanent kiosks and installations of water and electricity for them. However they did not do the same thing to the bird vendors as a part of their political programs. All $80 \quad(100 \%)$ respondents of culinary street vendors in Semarang were satisfied by both mayors' policy that facilitated them to improve their livelihood.

After Sumarmo had been released from the jail on $26^{\text {th }}$ September 2014, he and his competitor, Hendrar Prihadi, nominated themselves as the next mayoral candidates of Semarang Municipality for the period of 2016-2021. By the time of the election time, they both have personally attempted to attract public attention to obtain political gain. Recently, with reason of creating more opened green areas where Semarang only covered $7.5 \%$ of the total land while the national law required $20 \%$ of it, the local government would create more open green area. The local government then, in alliances with police and military, removed all traders of the P3B from their location in October 2014 as part of the government's program to meet its interest. However, the government's decisions that affected the future livelihood of the P3B entirely used top down approach which did not involve the bird street vendors to participate at all. Although the local government provided the second floor of the Karimata Market for street vendors to run their business, and the current Mayor re-announced the operation of the market on $18^{\text {th }}$ December 2014, the access to the area was poor so that only a small number of customers were willing to visit them, and now their future is totally in high risk. Moreover, the kiosks were too warm and uncomfortable for running the business. Statistic shows that all respondents $(100 \%)$ of bird traders of the P3B were dissatisfied by the current Mayor's policy. On the contrary, most authorized traders of Karimata Market (45 out of 50 respondents or 90\%) were satisfied with the recent policy, and only $10 \%$ were dissatisfied because of the getting more and more crowded situation of Karimata traditional market since the P3B traders had been relocated to the market.

\section{CONCLUSIONS}

The above accounts all suggest that although the local governments in Indonesia are in the reform era (where democracy is believed to be developed), neopatrimonialism features in the governance of street vendors in some areas - particularly those in Wonogiri District and Semarang Municipality - still persist. The local government treats the street vendors inconsistently and tends to marginalize them, and arbitrarily deprives them of their properties and employment. Local governments indeed have the legal power to set out under Local Law which did not include the street vendors as a part of the urban development planning. The Local Law suggests that the street vendors occupying an area projected for urban development should be removed or relocated to another place.

Street vendors have different levels of relationship with the local residents, the leaders of their locationbased groups, the leaders of the city-wide associations of street vendors, the state officials as well as the other power holders. In some cases they were even perceived as a disturbance of the public road users. Moreover, not all local residents or community groups welcome street vendors in their area because they perceive them as the source of public problems in their own residential areas, while the local government also perceives them as locallaw breakers and road-user disturbers. Those who have good relationships with the local residents and their leaders - while their leader had the capability to lobby the state officials or the power holder - tend to be advantaged. On the other hand, those who either does not have close personal relationship with local residents, including their leaders and the power holders, or if their leaders do not have lobbying, or if a power-holder himself has certain self-interest in a certain area, these street vendors tend to be disadvantaged. These differences seem to affect their level of survival on the street. Thus, creating social capital is essential for survival as a street trader in the urban areas in Indonesia, since the governance of street vendors is still characterized by the neopatrimonialism features.

\section{ACKNOWLEDGMENT}

Fund: Indonesian Directorate General of Higher Education, DIKTI 2014 and 2015 multi-year fund research project; Post Graduate Program of Sebelas 
Maret University 2012 DIPA annual fund research project.

\section{REFERENCES}

[1] Njaya, T. (2014). Challenges of Negotiating Sectoral Governance of Street Vending Sector in Harare Metropolitan, Zimbabwe, Asian Journal of Economic Modelling 2(2): 69-84

[2] McGee, T.G. \& Yeung, Y.M. (1977). Hawkers in Southeast Asian Cities: Planning for the Bazaar Economy. International Development Research Center, Ottawa.

[3] Morales, A. (2000). Peddling Policy: Street Vending in Historical and Contemporary Context, International Journal of Sociology and Social Policy, 20 (3): 76-97.

[4] Iyenda, G. (2005), Street Enterprises, Urban Livelihoods and Poverty in Kinshasa, Environment and Urbanization 17(2): 55-67.

[5] Suriansyah, Y. (2005). The existence of Street Vendors as a Reflection of Urban Life: Case Study of the Gasibu Area in Bandung, West Java, Indonesia. Journal of Asian Urban Studies 6(2): 43-50

[6] Anjaria, S.J. (2006). Street Hawkers and Public Space in Mumbai, Economic and Political Weekly 41(21): 2140-46.

[7] Bromley, R. (2000). Street Vending and Public Policy. A global Review, International Journal of Sociology and Social Policy 20(1-2): 1-19.

[8] Bhowmik, S. K. (2010), Street Vendors in the Global Urban Economy, New Delhi: Routledge.

[9] Tiwari, G. (2000). Encroachers or Services Providers? Seminar 491: 26-31.

[10] Adhikari, D. B. (2011). Income Generation in Informal Sector: A Case Study of the Street Vendors of Kathmandu Metropolitan City, Economic Journal of Development Issues 13\&14 (1-2) Combined Issue.

[11] Sethuraman, S.V. (1976). The Urban Informal Sector: Concept, Measurement and Policy, International Labour Review 114 (1): 69-81.

[12] Bhowmik, S. K. (2005). Street vendors in Asia: A Review, Economic and Political Weekly, May 28-4June, XL (22-23): 2256-64.

[13] Cross, J. (2000), Street Vendors, Modernity and Postmodernity: Conflict and Compromise in the Global Economy, International Journal of Sociology and Social Policy 20(1/2): 30-52

[14] Jimu, I. (2005). Negotiated Economic Opportunity and Power: Perspectives and Perceptions of Street Vending in Urban Malawi, Africa Development 30(4): 35-51

[15] Karthikeyan, R. \& Mangaleswaran R. (2013). Quality of Life among Street Vendors in Tiruchirappalli City, Tamil Nadu, India, International Research Journal of Social Sciences 2(12): 18-28

[16] Saha, D. (2011). Working Life of Street Vendors in Mumbai, the Indian Journal of Labour Economics 54(2): 301-325.

[17] Weber, M. (1978). Economy and Society. Berkeley: University of California Press.

[18] Pitcher, A., Moran, M.H. \& Johnston, M. (2009), Rethinking Patrimonialism and Neopatrimonialism in Africa, African Studies Review 52(1): 125-156.

[19] [19] Weber, M. (1965), Politics as a Vocation. In H.H.Gerth \& C.W.Mills (Eds), From Max Weber: Essays in Sociology, Philadelphia: Fortress Press.

[20] [20] Médard, J. (1982). The Underdeveloped State in Africa: Political Clientelism or Neo-patrimonialism? In: C. Clapham (ed.) Private Patronage and Public Power. London: Frances Pinter. pp.: 162-89.

[21] [21] Erdmann, G. \& Engel, U. (2007), Neopatrimonialism Reconsidered: Critical Review and Elaboration of an Elusive Concept', Commonwealth and Comparative Politics 45(1): 95-119

[22] [22] Reno, W. (2000). 'Shadow States and the Political Economy of Civil Wars', in Mats Berdal and David M. Malone (eds.), Greed and Grievance: Economic Agendas in Civil Wars. Boulder, Colo.[etc.]: Lynne Riener. Pp.43-68. URL: http://www.idrc.ca/en/ev-124432-201-1-DO_TOPIC.html (online accessed 28 April 2009)
[23] Ferguson, J. (2006). Global Shadows: Africa in the Neoliberal World Order. Durhamand London: Duke University Press.

[24] Cammack, D. (2007). The Logic of African Neopatrimonialism: What Role for Donors? Development Policy Review 25(5): 599 614.

[25] Scott, C.J. (1972). Patron-client Politics and Political Change in Southeast Asia, American Political Science Review 66(1):91-113.

[26] Gay, R. (1990), Community Organization and Clientelist Politics in Contemporary Brazil: A Case Study from Suburban Rio de Janeiro, International Journal of Urban and Regional Research 14(4): 648-65

[27] Auyero, J. (2000). The Logic of Clientelism in Argentina: An Ethnographic Account, Latin American Research Review 35(3): 55-81.

[28] Kelsall, T. (2011). Developmental Patrimonialism? Rethinking Business and Politics in Africa, Policy Brief 02, June, Africa Power and Politics.

[29] Sudarmo, (2009). Participation Efforts of Solo's Street Vendors in Policy Formulation during The Reform Era but Without Result, ALAR Action Learning and Action Research Journal 15(1): 107 140

[30] Pellini, A. \& Ayers, D. (2005). Social Capital and Village Governance: Experience with Village Networks, A Discussion Paper, November, Community Based Rural Development Project, GTZ.

[31] Sudarmo, (2011). Governance of Solo's Street Traders: A Critica Analysis Based on Empirical Research, Berlin: Lambert Academic Publishing.

[32] Ashiku, M. (2014). Economic Development and Social Capital in Albania", Journal of Economics and Development Studies 2(2): 469-482.

[33] Grafton, R. Q. (2005). Social Capital and Fisheries Governance, Ocean \& Coastal Management 48(9-10): 753-766.

[34] Woolcock, M. \& Narayan, D. (2000). Social Capital: Implications for Development Theory, Research and Policy, The World Bank Research Observer 15(2) 225-249.

[35] [35] Putnam, R. D. (1995). Bowling Alone: America's Declining Social Capital, Journal of Democracy 6(1): 65-78.

[36] Putnam, R.D. (1995a). Tuning In, Tuning Out: The Strange Disappearance of Social Capital in America, PS: Political Science and Politics 28(4): 664-683.

[37] Narayan, D. \& Pritchett, L. (1999). Cents and Sociability: Household Income and Social Capital in Rural Tanzania Economic Development and Cultural Change 47(4): 871-897.

[38] Woolcock, M. (1998). Social Capital and Economic Development: Towards Theoretical Synthesis and Policy Framework, Theory and Society 27(2): 151-208

[39] Pretty, J. (2003). Social Capital and the Collective Management of Resources, Science 32:1912-1914

[40] Cote, S. \& Healy, T. (2001). The Well-being of Nations: the Role of Human and Social Capital, Organisation for Economic Cooperation and Development (OECD) Paris.

[41] Woolcock, M. (2001). The Place of Social Capital in Understanding Social and Economic Outcomes, Isuma: Canadian Journal of Policy Research 2(1):11-17.

[42] Larsen, L. et al. (2004). Bonding and Bridging: Understanding the Relationship between Social Capital and Civic Action, Journal of Planning Education and Research 24: 64-77.

[43] Bandura, A. (1997). Self-efficacy. New York: W. H. Freeman and Company.

[44] Ostrom, E., Walker, J. \& Gardner, R. (1992), Covenants With and Without a Sword: Self- Governance Is Possible, American Political Science Review 86(2): 404-17.

[45] Steinberger, P. J. (1981). Social Context and Political Efficacy, Sociology and Social Research 65(2): 129-41.

[46] Bryman, A. (2009). Social Research Methods, ( $3^{\text {rd }}$ edn), Oxford: Oxford University Press.

[47] Boslaugh, S. (2007). Secondary Data Sources of Public Health: Practical Guides to Biostatistics and Epidemiology. $1^{\text {st }}$ edn. New York: Cambridge University Press. 